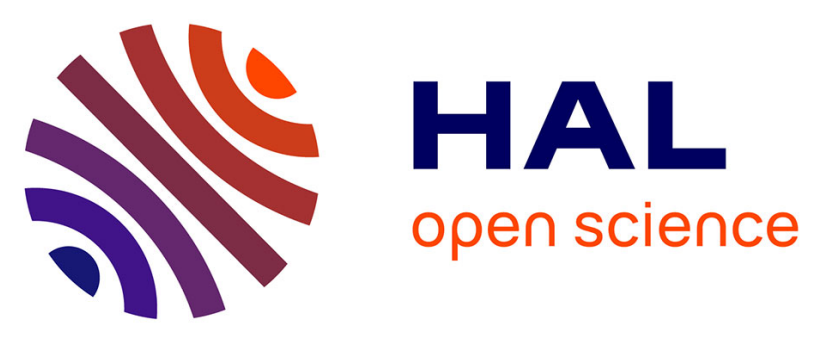

\title{
Spatiotemporal variation of a seed rain available for an endemic finch in an insular environment
}

Eduardo Garcia-Del-Rey, Nikos Nanos, Unai López-De-Heredia, Pascual Gil Muñoz, Rüdiger Otto, José María Fernández-Palacios, Luis Gil

\section{- To cite this version:}

Eduardo Garcia-Del-Rey, Nikos Nanos, Unai López-De-Heredia, Pascual Gil Muñoz, Rüdiger Otto, et al. Spatiotemporal variation of a seed rain available for an endemic finch in an insular environment. European Journal of Wildlife Research, 2010, 57 (2), pp.337-347. 10.1007/s10344-010-0438-1 . hal00629073

\section{HAL Id: hal-00629073 https://hal.science/hal-00629073}

Submitted on 5 Oct 2011

HAL is a multi-disciplinary open access archive for the deposit and dissemination of scientific research documents, whether they are published or not. The documents may come from teaching and research institutions in France or abroad, or from public or private research centers.
L'archive ouverte pluridisciplinaire HAL, est destinée au dépôt et à la diffusion de documents scientifiques de niveau recherche, publiés ou non, émanant des établissements d'enseignement et de recherche français ou étrangers, des laboratoires publics ou privés. 


\title{
Spatiotemporal variation of a Pinus seed rain available for an endemic finch in an insular environment
}

\author{
Eduardo Garcia-del-Rey • Nikos Nanos • Unai López-de-Heredia • \\ Pascual Gil Muñoz • Rüdiger Otto • José María Fernández-Palacios • Luis Gil
}

Received: 17 March 2010 /Revised: 14 September 2010 /Accepted: 15 September 2010/Published online: 5 October 2010

(C) Springer-Verlag 2010

\begin{abstract}
A major goal of avian ecological research is to determine how distribution and abundance of preferred resources available influence population dynamics and contribute to understand life-history characteristics. Food is widely considered the ultimate factor influencing these traits. We studied, with seed traps, the spatiotemporal variability of Pinus canariensis seed rain during 2007-2008, as a means to explain why a post-dispersal seed predator of conservation concern, the endemic blue chaffinch Fringilla teydea, can adjust its annual life cycle with this variation in an insular environment. Generalized linear mixed models and geostatistical tools were used. Results highlight that temperature and relative humidity are important predictors of seed release rates. Additionally, a high temporal variation was detected in seed abundance (i.e., peaks of massive seed release during the summer months, intermediate values in the autumn, and minimum release rates in winter and spring). Finally, withinstand spatial variation in seed flux was surprisingly large with the most productive microsites receiving three to four times more seeds than the least productive ones. Pine seeds showed a high protein value and a low germination rate.
\end{abstract}

Communicated by C. Gortázar

E. Garcia-del-Rey $(\bowtie) \cdot$ R. Otto $\cdot$ J. M. Fernández-Palacios

Departamento de Ecología, Facultad de Biología,

Universidad de La Laguna,

38206 La Laguna, Tenerife, Canary Islands, Spain

e-mail: edugdr@ull.es

N. Nanos $\cdot$ U. López-de-Heredia $\cdot$ L. Gil

School of Forest Engineering, Technical University of Madrid,

Ciudad Universitaria $\mathrm{s} / \mathrm{n}$,

28040 Madrid, Spain

P. G. Muñoz

Sección de Montes, Medio Ambiente, Cabildo Insular de Tenerife, Santa Cruz de Tenerife 38200 Canary Islands, Spain
Based on these findings, we suggest that the fortunes of the blue chaffinch should be intimately related to spatiotemporal annual $P$. canariensis seed crops, temperature acting as a proximate cue, and food availability as the ultimate factor. For the endangered blue chaffinch population on Gran Canaria, we recommend, until more data are available, improving the seed supply during the winter season, either artificially (feeders) or naturally (planting Myrica faya shrubs).

Keywords Mediterranean $\cdot$ Fringilla teydea $\cdot$ Pinus canariensis · Seed trap · Seed rain · Canary Islands . Conservation implications

\section{Introduction}

A major goal of avian ecological research is to determine both the role of birds in determining structure and functioning of ecological communities and how distribution and abundance of preferred resources available in those communities influence dynamics of populations and interactions among species (Wiens 1977, 1989). Information on food availability alone has contributed to the understanding of numerous life-history characteristics and their population and community-level consequences (Smith and Rotenberry 1990). Of biological parameters that might influence the evolution of adaptations among species, the distribution and abundance of their main food resource are especially important (Krebs and Davies 1987). Generally, sampling avian food resources in a meaningful manner is a difficult problem that, in some cases, seems nearly impossible and intractable, particular in complex communities (Smith and Rotenberry 1990) or for particular seed-eating species (Sutherland et al. 2004). Indirect studies are often used when information is practi- 
cally impossible to obtain (Newton 1999), and indirect diet assessments can help answer a wide range of important ecological questions (Sutherland et al. 2004).

The worldwide distribution of Pinus comprises primarily large parts of the northern hemisphere (e.g., North America, Mexico and Central America, northern Asia, Europe, and the Mediterranean Basin; Critchfield and Little 1966), but also some islands (e.g., Hispaniola and Western Cuba in the Caribbean Basin, Britain in northern Europe, Corsica and the Canary Islands in the Mediterranean Basin, Japan and its related islands in Asia; Richardson and Rundel 2000). Worldwide very few bird species have been able to specialize on the seed crop of Pinus alone (Clement et al. 1993). The most widespread are the four species of the Loxia crossbills (Clouet 2000), all with specialized crossed mandibles for extraction of the seeds from either ripe or green cones (i.e., pre-dispersal seed predators). In addition, a corvid, the Clark's nutcracker Nucifraga columbiana, has a seed dispersal mutualism with Pinus in both Europe and North America (i.e., seed predator-disperser; Siepielski and Benkman 2007), although other members of this family also cache pine seeds in North America (e.g., pinyon jay Gymnorhinus cyanocephalus). Other European finches, such as siskin Carduelis spinus, common chaffinch Fringilla coelebs, and brambling Fringilla montifringilla, also take pine seeds but only when the cones open (i.e., post-dispersal seed predator).

Interannual variation in tree seed set and dispersal in continental regions depend greatly on the intrinsic characteristics of the tree species themselves and partly on the weather conditions; hence, the total production of pine seeds over a continent varies greatly from year to year (Keeley and Zedler 2000). Seed eaters in continental areas, notably crossbills, which depend on variable seed crops, respond to poor crop years (i.e., crop failures) through "irruptive" movement which can occur on a huge spatial scale. These irruptions have been well documented in Europe (Newton 2006a, b; Marquiss et al. 2008) and North America (Bock and Lepthien 1976) and are remarkable in the synchrony between species and sometimes also between continents, often attributed to circumboreal climatic events that bring fruiting of different tree species on both continents into phase (Newton 1998). In contrast, island forms that depend on pine seeds cannot track spatial and temporal variation in food abundance through "irruptive" behavior.

Based on their distributional range (i.e., only inhabiting Pinus canariensis forest), two endemic bird species have been traditionally considered pine forest specialists in the oceanic archipelago of the Canary Islands (Volsoe 1955): the great spotted woodpecker Dendrocopos major canariensis (Garciadel-Rey et al. 2007b) and the blue chaffinch Fringilla teydea (Bannerman 1963). However, the latter is the only true seed eater (Snow and Perrins 1998; Garcia-del-Rey and Gosler 2005). This sexually dimorphic finch (Garcia-del-Rey and
Gosler 2005), a post-dispersal pine seed predator (i.e., takes dispersing seeds on the ground and off the back of open cones), depends mainly on pine seeds when available (Garciadel-Rey et al. 2009), but other seeds are also exploited during the winter months in lower mixed forest areas (Garcia-delRey and Cresswell 2005). Two races occur on this archipelago; the nominate race is found on Tenerife and polatzeki on Gran Canaria; the latter is in the brink of extinction, due to habitat fragmentation, degradation, and wildfires and therefore of conservation concern (BirdLife 2004).

This study aimed to investigate the temporal and spatial variation of the pine seed crop as a means to explain how an endemic island pine seed eater, of conservation concern, can adjust its annual life cycle with variation in their main food resource. We also analyzed the nutrient content of the island pine seed to try to understand the quality of this food resource; we also compare it with other Pinus seeds elsewhere in continental regions. Finally, we recommend conservation actions for the endangered population of blue chaffinch on Gran Canaria.

\section{Material and methods}

\section{Experimental plot}

The seed release rate of $P$. canariensis was monitored in an experimental plot ( $2 \mathrm{ha})$ established in a pure and even aged stand of the species, located in the northeastern part of Tenerife (Fig. 1). Trees of the plot were mapped using a total (topographic) station. We also measured the breastheight diameter with a digital caliper. Ten percent of the counted trees were randomly selected for measuring the total tree height. In April 2007, we placed 103 seed traps on the nodes of a pseudo-regular grid covering the full area of the experimental plot (Fig. 2a). Traps were circular $(0.55 \mathrm{~m}$ in diameter) with a wire mesh of (c. $30 \mathrm{~mm}$ in diameter) on their top to avoid seed removal by birds or mammals. Traps were visited every 7 to 42 days from May of 2007 until November of 2008 (we were not expecting high seed release during the winter months according to the descriptive literature). Seeds were transported to the lab, weighed, and classified as sound or empty. Several weather variables, such as mean temperature, average relative humidity, and wind velocity, were also registered from official stations less than $5 \mathrm{~km}$ away from the study site.

Statistical analysis

\section{Meteorological effects on seed release rates}

We study the effect of meteorological conditions on the observed seed release rates using the general linear model 

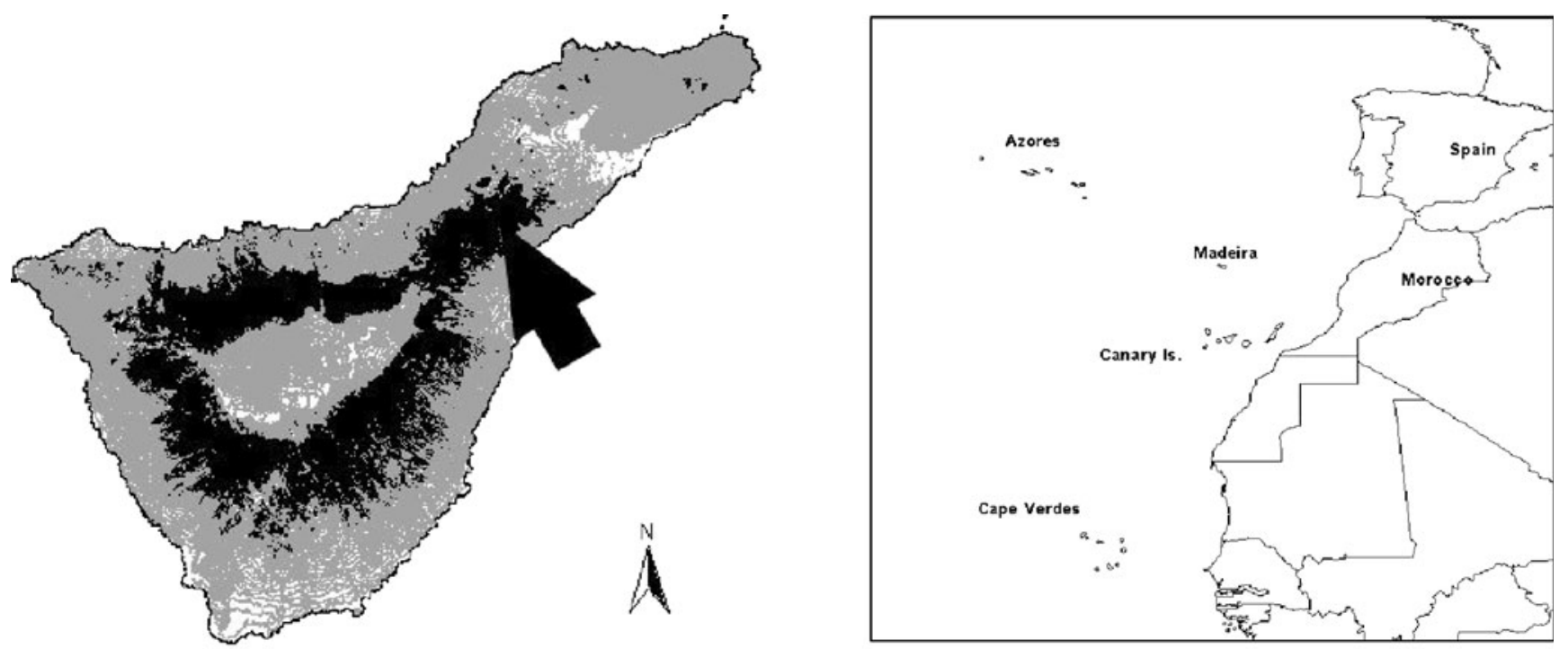

10 Kilometers

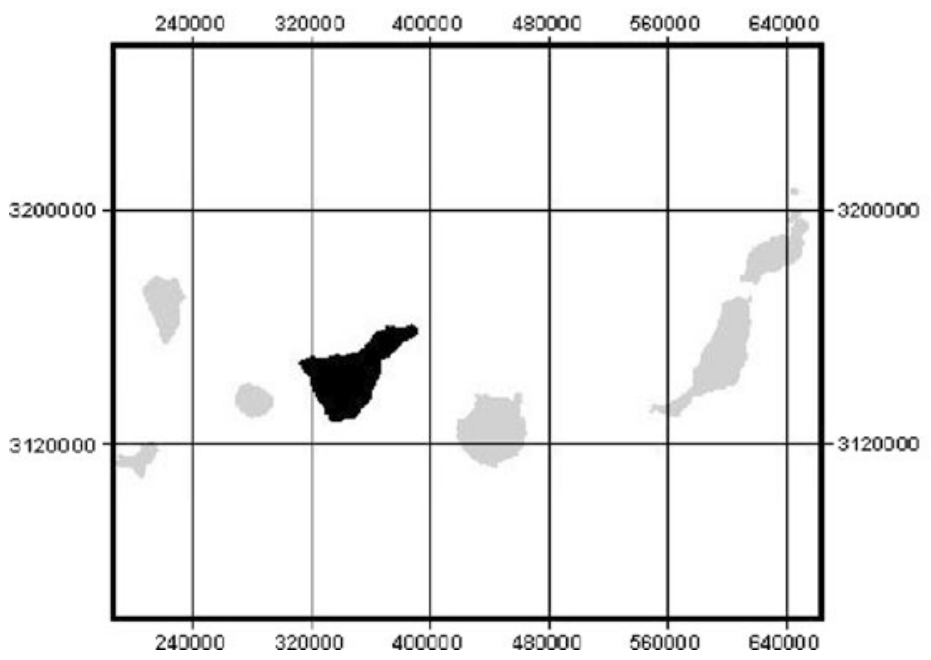

Fig. 1 Location of study site (arrow) in the P. canariensis forest (black) on the island of Tenerife, Canary Islands, Spain

(GLM) and allowing for temporal autocorrelation for the successive seed counts. Let $i(i=1, \ldots 103)$ indicate the trap number and $j(j=1, \ldots, 55)$ the seed collection campaign. To study the meteorological effects on the seed release rate for the entire stand, we suppressed the spatial variability (i.e., trap-to-trap variation) by summing the seed count data over the 103 seed traps for every seed collection campaign. The logarithm of the total number of seeds captured in the $j$ th campaign, $\log \left(\sum_{j=1}^{103} Y_{i j}+1\right)$, was approximately Gaussian (normality was checked with quantile-quantile plots). The candidate meteorological variables considered to affect the seed release rates from adult trees were the average and the maximum of the minimum, maximum, and mean daily temperatures during the days preceding seed collection and the same variables for relative humidity. Additionally, we considered maximum wind velocity, total precipitation, and evapotranspiration. An offset term with no attached parameters was also introduced into the model to standardize for the number of days between two successive seed collection campaigns $(j$ and $j+1)$ that can vary across campaigns (from 6 days during the hot summer months up to 42 days during the winter period). The postulated model includes, furthermore, an additional parameter ("Phi") of an AR1 autoregressive term, which was included in the model due to the temporal autocorrelation for data coming from successive collection campaigns. Parameter estimation was based on maximum likelihood using the "gls" function of the "nlme" library of R (Pinheiro and Bates 2000). The best model (i.e., the model with the optimal combination of explanatory variables) was decided using the "dropl" function of the same R-library that computes the fit statistics for all the 


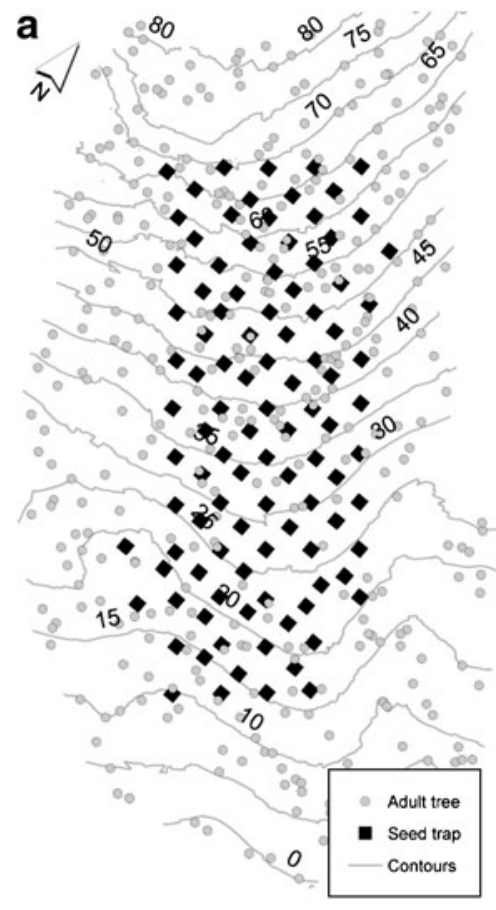

Fig. 2 Maps of the experimental plot showing a the trap and the adult tree locations as well as the contour lines (the relative altitude is shown), b the predicted random trap effects estimated through Eq. 1,

possible variables that can be extracted from the full model. Residual plots were finally used to assess the validity of the GLM assumptions.

\section{Spatial and seasonal variability of seed release}

We postulated a second model to study the spatial and temporal variability of the seed release rates in the experimental plot. The raw response variable (seed counts for every trap and collection campaign) could not be transformed to normality (several zeros existed in the data set) so we postulated a generalized linear mixed effect model (GLMM) with a Poisson response and three random effects. The linear predictor of the model is:

$\log \left(\mu_{i l j}\right)=\log \left(\operatorname{days}_{l j}\right)+\beta+u_{i}+w_{l}+v_{l j}$

Such a formula splits the response into a fixed part $(\beta)$ and three random components modeling the spatial (i.e., random trap effects, $u_{i}$ ) and the temporal variation, with both random year effects $\left(w_{l}\right)$ and collection campaign within year $\left(\mathrm{v}_{l j}\right)$ effects. The offset term, days $\mathrm{s}_{l j}$, with no attached parameters, is used to standardize the seed counts over the 55 time periods that may have different duration.

Note that we consider time (i.e., the collection campaign) as a random effect allowing for additional flexibility in the model outcome. If we consider the collection campaign as a fixed effect, we need to estimate too many

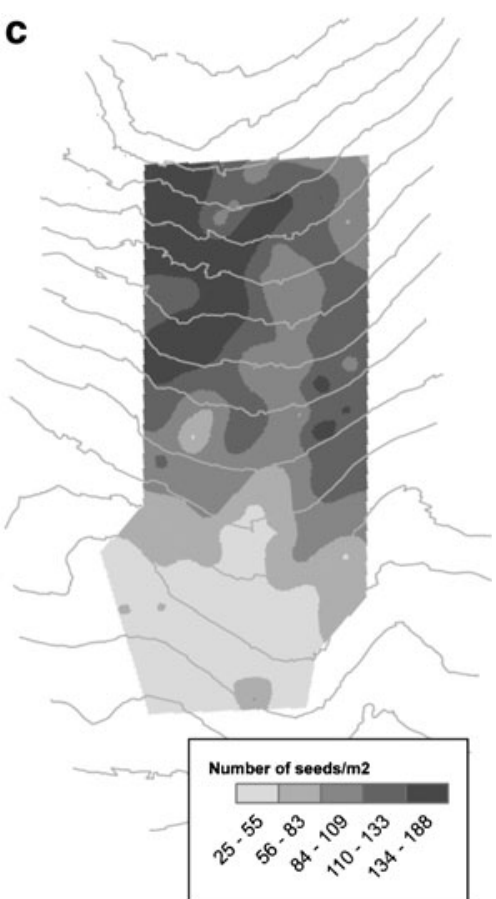

and $\mathbf{c}$ the estimated (by IRF- $k$ kriging) number of seeds per unit surface over the whole study period

parameters (one for every campaign) and interpretation would be extremely difficult given the high temporal variability observed in the seed flux (see the "Results" section). Before building this model, we inspected our data for over-dispersion by postulating models with a quasiPoisson dispersion parameter and estimating weather the estimated dispersion was indicative of over-dispersion.

Model fitting was based on restricted maximum likelihood (REML) using the "glmer" function of the "Ime4" Rlibrary (Bates 2005). This function presents the advantage to use a Laplacian approximation to the likelihood, a method that has been reported as more reliable when the mean number of counts is smaller than 5 (Bolker et al. 2009). Finally, we used likelihood ratio tests (LRT) to compare the full model (with three random effects) against the alternative (and simpler) models having either only spatial or temporal random effects on the seed counts. LRT tests are recommended when comparing GLMMs with different random effects (Bolker et al. 2009).

\section{Spatial prediction of the seed flux}

We used geostatistical tools to map the spatial distribution of the seed flux as well as to study its spatial structure. We calculated the experimental variogram for the total (i.e., the bi-annual) number of seeds captured in the traps, and subsequently, we used kriging techniques to estimate the total number of seeds per square meter arriving in the forest 
floor. The analyzed regionalized variable (i.e., the total number of seeds in the $i$ th trap) cannot be considered intrinsically stationary (see the "Results" section), and consequently, its spatial structure and estimation was realized based on the theory of intrinsic random functions (IRF) of order $k$. The theory of IRF- $k$ was developed to cope with non-stationary phenomena (Chilés and Delfiner 1999). Under the IRF- $k$ framework, the regionalized variable indicated by $Z(\mathbf{x})$ is decomposed into two components

$Z(\mathbf{x})=m(\mathbf{x})+Y(\mathbf{x})$

the deterministic drift $m(\mathbf{x})$, which is a function of the spatial coordinate vector $\mathbf{x}=\left(x_{1}, x_{2}\right)$, and $Y(\mathbf{x})$, a spatially correlated random function with zero mean and spatial covariance $K(\mathbf{h})$. The spatial covariance (generalized covariance, GC) is a nested isotropic covariance model written as:

$K(\mathbf{h})=\sum_{p=0}^{k}(-1)^{p+1} b_{p}|h|^{2 p+1}$

with unknown parameters $b_{p}$.

In practice, IRF- $k$ modeling implies deciding the best combination of the degree of the drift function, $m(\mathbf{x})$, and the best GC function that is compatible with the degree of the previously chosen drift. The former is decided after multiple drift functions are adjusted (by least squares) to the data that are subsequently ranked according to the errors produced by each one of them. On a second step, we estimate the parameters of the $\mathrm{GC}$ that provide the best fit to the data using a cross-validation procedure (for a detailed description, see Chilés and Delfiner 1999, and for the practical implementations, see Isatis 2008, which is the software that we have used in this study).

\section{Seed germination tests}

Germination tests were performed to have an estimate of the seed bank remaining in winter (after the first rainfalls promote germination). For these tests, we used a total of 362 seeds harvested from the seed traps during the summer and autumn period of 2007. For seeds released during the summer period, we used all the seeds harvested from the seed traps on the 10th of August (15th collection campaign). For studying the germination in seeds released in autumn, we used all the seeds collected from the seed traps between the 28th of September of 2007 and the $21 \mathrm{st}$ of December of the same year. First, the percentage of useless seeds was scored by submersion in water for $24 \mathrm{~h}$. Floating seeds were considered to be empty, therefore unable to germinate and not available for the blue chaffinch. Afterward, 324 potentially viable seeds were placed on a perlite substrate in a germination chamber with a day temperature of $22^{\circ} \mathrm{C}$ and $80 \%$ of humidity. The germinated seeds were counted every day because of the high germination ability. A seed was considered "germinated", when the length of the root was equal to the double of the seed. Germination curves were constructed for summer and autumn seeds separately.

\section{Nutrient content analysis of pine seeds}

A portion of randomly selected captured seeds was analyzed for nutrient content. Percentages of humidity (Dir. 71/393/CEE Met 1), ashes (Dir. 71/393/CEE Met 5), raw protein (MT/AG/PH/006), raw fat (MT/AG/PH/007), raw fiber $(\mathrm{MT} / \mathrm{AG} / \mathrm{PH} / 008)$, and carbohydrates were obtained following the methods within brackets. The percentages of raw protein, raw fat, and carbohydrates were compared with the values for other pine species in continental regions reported in the literature.

\section{Results}

The experimental plot was installed in a typical mature pine forest of Tenerife (López et al. 2008) with an average stem density of 163 stems/ha that varied locally from a minimum of $63 \mathrm{stems} / \mathrm{ha}$ up to $247 \mathrm{stems} / \mathrm{ha}$. The average basal area was $36.5 \mathrm{~m}^{2} /$ ha varying from 10 to $55 \mathrm{~m}^{2} /$ ha. Trees had on average $51.7 \mathrm{~cm}$ of diameter with larger trees reaching $90 \mathrm{~cm} \mathrm{DBH}$. The mean tree height was $26.9 \mathrm{~m}$.

Figure 3 displays the main features of the seed release rates. The average seed flux during the 20-month period was 0.22 seeds $/ \mathrm{m}^{2}$ day. $P$. canariensis released massively its seed during July and August, when the average temperature reached $24 \mathrm{C}$ approximately. However, temporal variation was high with a maximum of seed release on August 10th 2007 (2.11 seeds $/ \mathrm{m}^{2}$ day) and on July 7th 2008 ( 0.8 seeds $/ \mathrm{m}^{2}$ day) and a minimum during winter and spring months (we recorded no seeds in the seed traps on the 1 st of June 2007 or the 1st of February 2008). During the autumn months, we observed intermediate release rates (for instance, we captured 0.18 seeds $/ \mathrm{m}^{2}$ day on the 9 th of November 2007 and 0.3 seeds $/ \mathrm{m}^{2}$ day 11 th of October of 2008).

Meteorological effects on seed release

The best model for the total seed counts in the traps for each collection campaign included only the average of the mean daily temperature and relative humidity during the days preceding seed collection (Table 1). Other meteorological variables such as wind velocity, precipitation, or evapotranspiration were not significant and were removed 
Fig. 3 Average daily seed flux (average number of seeds per square meter and day) registered in the seed traps during 2007 and 2008 and average minimum temperature during the days preceding seed collection in the seed traps

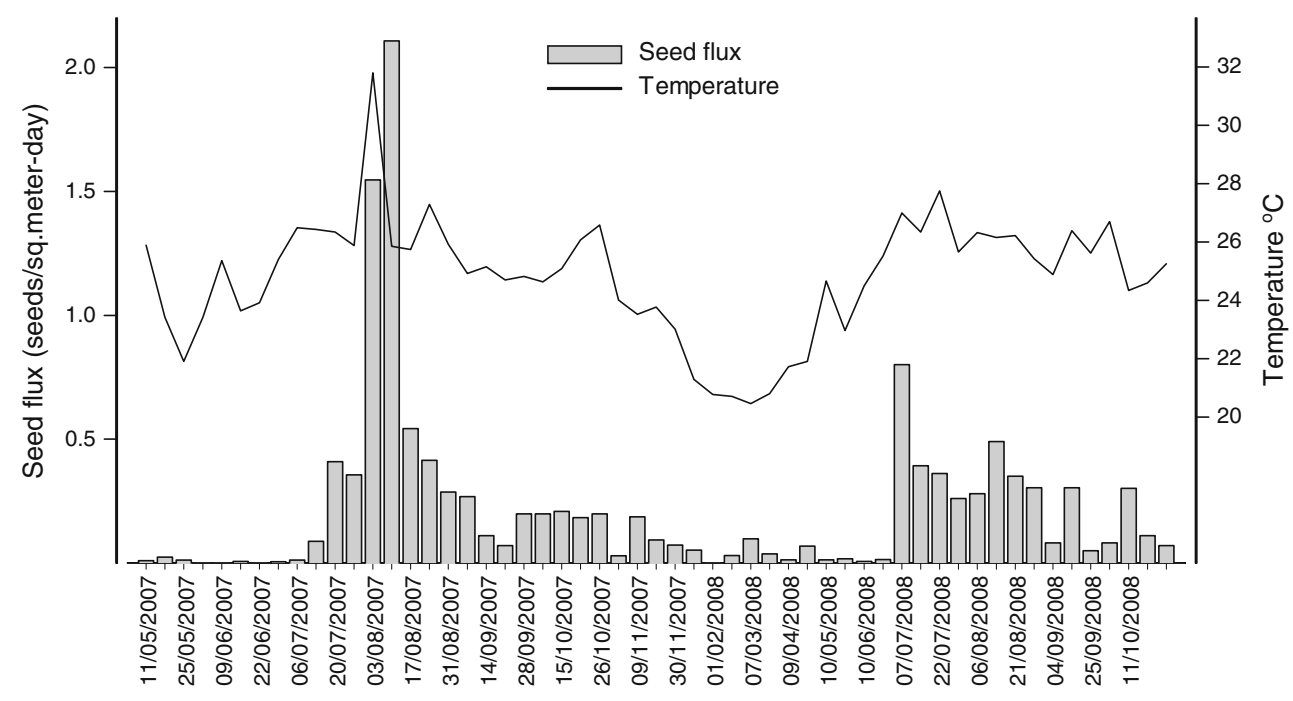

from the model. Standardized residual plots and quantilequantile plots for the residuals (not shown) showed no significant departures from the classical regression assumptions. The estimated "Phi" parameter $(=0.62$, Table 1$)$ indicated significant autocorrelation in the data coming from successive seed counts of the same trap $(95 \%$ approximate confidence interval $0.38-0.78$ ).

Spatial and temporal variability of seed release

The dispersion parameter of the initial (quasi-Poisson) model build for the spatiotemporal variability was smaller than unity (0.48) indicating that over-dispersion is not a problem for our data; therefore, the subsequent models were built using the Poisson distribution for the response variable.

When the full model (Eq. 1) was adjusted to the data by REML, the estimated variance for the random year effect was zero, indicating that year-to-year variability was not significant; it was therefore automatically excluded from the model as a random effect. Additionally, the exclusion of spatial random effects from the full model did not provide better fit to the data $\left(x_{1}^{2}=195.66, p=0.000\right)$. Similar results were obtained when we removed the temporal

Table 1 Parameter estimates for the meteorological model affecting seed flux

\begin{tabular}{lrcrc}
\hline Parameter & Estimate & Standard error & $t$ value & $\operatorname{Pr}>|t|$ \\
\hline Intercept & -9.72 & 3.42 & -2.84 & 0.0064 \\
$T$ & 0.38 & 0.11 & 3.30 & 0.0017 \\
RH & 0.07 & 0.02 & 2.98 & 0.0043 \\
Phi & 0.62 & & & \\
\hline
\end{tabular}

Intercept parameter estimates for the intercept, $T$ the average of the mean daily temperature, $R H$ relative humidity, $P h i$ autocorrelation parameter of the AR1 autoregressive term random effects and comparing with the full model $\left(x_{1}^{2}=4,075.4, p=0.000\right)$. Conclusively, the final model included spatial and temporal effects for the seed flux in the traps, but it did not include any year-to-year variability.

According to the model fit statistics, the variability of the seasonal effect (1.68) is four times larger than the variability of the spatial (trap) effect ( 0.42 , see Table 2$)$.

Several random temporal effects (shown in Fig. 4 along with their $95 \%$ prediction interval) do not include zero in their prediction intervals. A large negative random effect was observed for the 29th campaign made during the cold winter months of January and February of 2008. In Fig. 4, we can also identify two time periods with large negative random effects with prediction intervals that do not include zero. The first one extends from May to mid-July of 2007 and the second one from March to mid-July of 2008. Large positive random effects, however, were observed during the hot summer and autumn months of 2007 and 2008 (Fig. 4).

As regards the spatial variability, several random trap effects did not include zero in their prediction interval (random effects plot not shown). A plot of random trap effects over the experimental plot (Fig. 2b), however, shows that these effects are spatially structured with high

Table 2 Parameter estimates for the spatiotemporal model of seed flux obtained via REML and a Laplacian approximation of the likelihood

\begin{tabular}{lcccc}
\hline Parameter & Estimate & Standard error & $z$ value & $\operatorname{Pr}>|z|$ \\
\hline Fixed effect $(\beta)$ & -4.07 & 0.23 & -17.23 & 0 \\
$\begin{array}{l}\text { Standard } \\
\text { deviation }\left(u_{i}\right)\end{array}$ & 0.42 & & & \\
$\begin{array}{c}\text { Standard } \\
\text { deviation }\left(v_{l j}\right)\end{array}$ & 1.68 & & & \\
\hline
\end{tabular}

$u_{i}$ and $v_{l j}$ are the random trap and collection-campaign effects of Eq. 1 


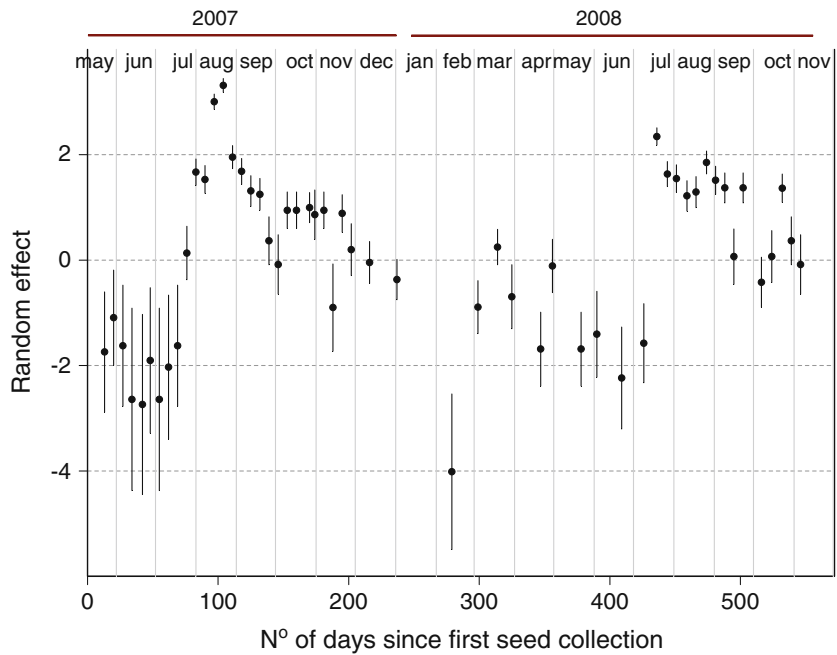

Fig. 4 Predicted random temporal effects versus time. The associated lines (for random effects) indicate the $95 \%$ prediction intervals

positive values reached for the northern part of the experimental plot (that happens to have a higher altitude) and large negative effects for the lower part of the plot (the spatial variability in seed flux is further described in the next section).

Spatial prediction of the seed flux

In accordance to the results on the spatiotemporal variability of seed flux, differences in seed flux among traps were found to be location dependent as revealed by the experimental variograms for the total seed crop (Fig. 5). The experimental variogram lacks a visible sill, implying that the bi-annual seed crop is a non-stationary variable (i.e., drift in the mean number of captured seeds is present in the experimental plot). The spatial drift, which is present mainly in the $160^{\circ}$ direction (directional variograms are shown in Fig. 5) following the altitudinal gradient made

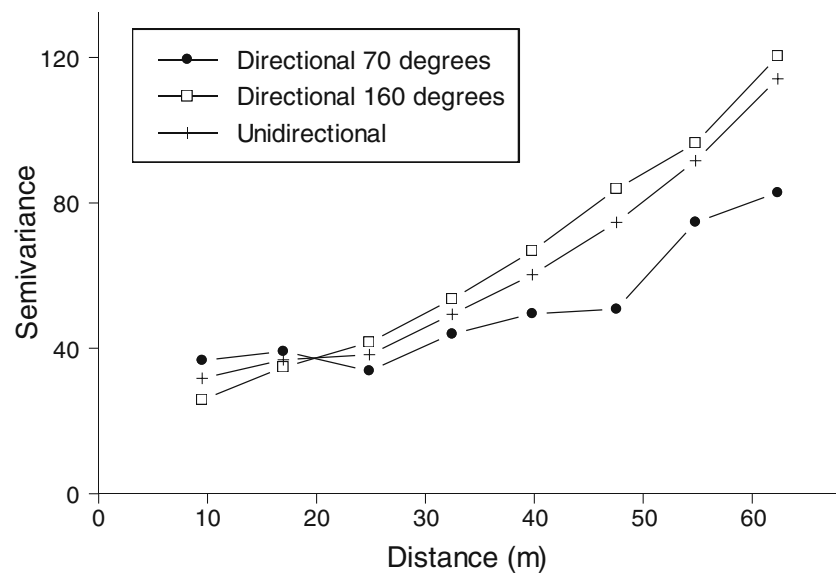

Fig. 5 Experimental variograms for the total number of seeds received in the traps seed arrival to be much larger in the upper part of the experimental plot. Due to the detected drift, we employed IRF- $k$ theory to make the prediction map for the seed flux. Results of this analysis showed that the best drift model includes the following terms:

Constant $+x+y+x^{2}+x y+y^{2}$

being $x$ and $y$ the spatial coordinates of the location to be estimated. The best GC was a spline function with estimated parameter $b_{p}=32.45$.

The prediction map for the bi-annual seed crop produced via the best combination of drift and GC is presented in Fig. 2c. According to these predictions, the lower part of the plot received much less seeds than the upper part, revealing very large within-stand variability in the seed production (in accordance to the results of the spatiotemporal variability).

\section{Seed germination tests}

The percentage of useless seeds was $44.5 \%$ for summer seeds and $58.9 \%$ for autumn seeds. The germination test was performed for 62 days. At the end of the experiment, the percentage of germination was $78 \%$ for summer seeds and $56 \%$ for autumn seeds (Fig. 6), i.e., there still is an important number of pine seeds available for blue chaffinches in winter $(22 \%$ of summer seeds $+44 \%$ of autumn seeds). The process of germination initially began at the same time for both types of seeds during the first 2 weeks of observations; then, the rates of germination of both seed sources diverged. A rapid increase of germination was observed in summer seeds between the 18th and the 25th days of observation. After that, little increase was observed until the 52nd day when the rate of germination leveled off until stabilization.

Nutrient analysis of the pine seeds

Table 3 shows the composition of the pine seed collected. Compared to other pines, Canary Island pine seeds show a high percentage of raw protein of $39.4 \%$, with correspondingly lower percentages of raw fat (39.8\%) and carbohydrates (10.2\%; Table 4). P. canariensis seeds are therefore a high protein food resource but lower in calorific value.

\section{Discussion}

Spatial variation of the seed flux

Overall, our study reveals very large within-stand spatial variation in seed production with some microsites receiving 


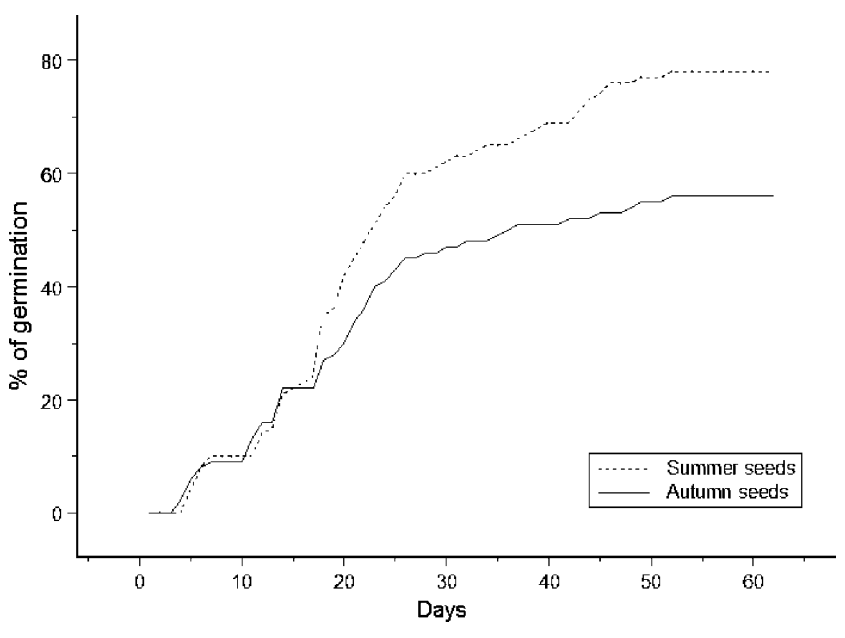

Fig. 6 Germination curves for summer and autumn seeds

just $25-55$ seeds $/ \mathrm{m}^{2}$ while others reaching $134-188$ seeds $/ \mathrm{m}^{2}$ over the 19-month study period (see the prediction map of seed flux in Fig. 2c). These results support some previous findings that report that the highly aggregated distribution of habitat selection by blue chaffinches for the winter months (Garcia-del-Rey et al. 2009) is due to differences in the food availability of the habitat; our results further indicate that some breeding territories could be better, in terms of pine seed abundance, than others. Garcia-del-Rey et al. (2009) suggested that pine seed abundance and availability (along with perceived predation risk and overall availability of safe foraging options) was responsible for the winter feeding behavior of blue chaffinches. Food is widely considered the ultimate factor influencing spatial distribution and foraging behaviors of birds (e.g., Buckingham and Peach 2006) and how sedentary birds on islands, as the blue chaffinch, can cope with this high spatial variation of food deserves future research at the most precise spatial scale (i.e., home range or territory size).

Based on the results of this study, we cannot conclude on the stand- or tree-specific factors provoking such a remarkable within-stand variability in seed production, especially when working within such a small forest area (2 ha). However, individual seed production by pine

Table 3 Composition of pine seeds (Tenerife, Canary Islands)
Table 4 Dietary value of pine nuts for ten pine species (Lanner, 1981), including P. canariensis (this study)

\begin{tabular}{lclc}
\hline Species & Protein (\%) & Fat (\%) & Carbohydrates (\%) \\
\hline Pinus canariensis & 39.4 & 39.8 & 10.2 \\
Pinus edulis & 14 & $62-71$ & 18 \\
Pinus monophylla & 10 & 23 & 54 \\
Pinus cembroides & 19 & 60 & 14 \\
Pinus x quadrifolia & 11 & 37 & 44 \\
Pinus sabiniana & 30 & 60 & 9 \\
Pinus strobiformis & 28 & 52 & 7 \\
Pinus pinea & 34 & 48 & 7 \\
Pinus sibirica & 19 & $51-75$ & 12 \\
Pinus gerardiana & 14 & 51 & 23 \\
Mean & 23.44 & 45.63 & 18.95 \\
\hline
\end{tabular}

species has been shown to depend on several factors such as maturity, tree size, and competition by conspecifics (Clark et al. 2004; Uriarte et al. 2005; Calama et al. 2008; Schurr et al. 2008).

Meteorological effects and high temporal variation

This study highlights the importance of both mean temperature and relative humidity, for the phenology of cone opening and, consequently, seed dispersal in $P$. canariensis, a pattern of seed release found also for other pine species in the Mediterranean basin (Nathan et al. 1999; Tapias et al. 2001). Elsewhere, including the Mediterranean region, pine cones mature in late summer to early autumn, then dry and open immediately and shed their winged seeds on the wind (Lanner 1981, 1998). The blue chaffinch has been traditionally considered as a late breeder in the Canary Islands, including on Tenerife (Garcia-del-Rey 2008), because females lay eggs in either late May or mid-June (Snow and Perrins, 1998), when compared to other pine forest bird passerines that lay their eggs much earlier on average (Garcia-del-Rey 2003; Garcia-del-Rey et al. 2006, 2007a). However, no plausible explanation for this lifehistory trait has been postulated in the literature (Snow \& Perrins 1998). Warm temperatures and number of pine cones in territory seem to influence the onset of reproduction of other pine forest endemics in Mediterranean islands (Thibault and Villard 2005).

The fact that the random year effect was excluded from our full model of spatiotemporal variability (Eq. 1) indicates that year-to-year variation in seed production is not actually important, or at least not detected by our study. This result suggests that, based on our 19 month data, $P$. canariensis is maintaining a rather stable seed production across years and that masting seems to be not 
relevant. Should this be the case, the blue chaffinch should preserve a rather stable population size across years in close relation to its main food source which has a high protein value. However, conclusions on the interannual variability in the seed set of this species should not be considered as definite since our data expand over a rather small time period. Fluctuating seed crops and bird populations are almost the rule elsewhere in continental regions (Newton 1998).

Our findings also suggest a high temporal (i.e., seasonal) variation in seed flux in $P$. canariensis with peaks of massive seed release during the summer months, intermediate values in the autumn, and minimum release rates in winter and spring. However, germination tests have shown that a remarkable percentage of summer and autumn released seeds do not germinate being available in winter for blue chaffinches. Birds are selected to breed as early as they can (Perrins 1979), and life-history traits associated with breeding (e.g., laying date) are assumed to be determined by natural selection in such a way as to maximize the production of offspring (Baker 1938). Avian vertebrates should, therefore, reproduce at those times of the year when the offspring have the highest chances of survival, and egg laying must start several weeks before the food supply reaches a peak if the parents are to have their young in the nest at the best time (Perrins 1970). Although temperature can stimulate arthropod abundance and consequently female breeding condition to produce eggs, blue chaffinch productivity is extremely low and most pairs raise on average two chicks a year (Naurois 1986; Snow and Perrins 1998; Garcia-del-Rey 2008). We hypothesize that the blue chaffinch is a late breeder in the $P$. canariensis forest because it is trying to synchronize the nestling stage (i.e., chicks in the nest) with the pine seed peak of food supply, their most important food resource if available. Hence, life-history traits associated with breeding for this finch seem to be intimately related to the pine seed rain, temperature acting as a proximate factor or cue, and food (arthropods and pine seeds) as the ultimate factor. If synchronization occurs, we should expect that a blue chaffinch female start laying the first egg 27 days earlier than the peak of pine seed dispersal (i.e., 1 day for every egg, 15 days for incubation, and 10 days for the chicks to reach the highest energy demands). Conversely, if a female blue chaffinch is not able to synchronize, chicks will also be at an advantage when fledgling because pine seeds will be at its maximum abundance then (Garcia-del-Rey 2008). Such a relationship between cone crop and reproduction occurs with other seedeating passerines in both mainland and islands elsewhere (Shaw 1990). The high protein seed content found in this study is striking, and seeds may meet the nutritional needs of chicks when arthropods are low. Until a detail analysis of nestling diet composition is available (difficult in practical terms), we can only suggest that late or second broods could be raised on pine seeds alone (Newton 1972), but this will have to be studied in the future.

In this island scenario, sedentary birds can only shift to other food resources or move to better feeding areas. So how can the blue chaffinch cope with minimum release rates in winter and spring? Elsewhere in continental areas, pre-dispersal seed eaters, such as crossbills, move long distances in response to local or regional changes in their main food supply (Newton 2006a). Their objective is to breed in areas of good crops, as they can, if necessary, feed their young on seed alone (Newton 1972). Conversely, the Clark's nutcracker survives on cached pine seeds in the soil during autumn and winter and plays an important biological role in dispersing pine seeds (Lanner 1996). For obvious reasons, long distance movement emerges as a less significant factor in an island ecosystem as the pine forest of Tenerife. No gene flow has ever been detected between the Canary islands for the endemic blue chaffinch (Pestano et al. 2000), although inter-island movement by finches has been recorded on other oceanic islands as the Galapagos (Boag and Grant 1984; Gibbs and Grant 1987; Grant 1998). In the Canary Islands, only short altitudinal movement (color ringed birds) has ever been recorded on Tenerife (i.e., $4 \mathrm{~km}$ from breeding site; Sociedad Ornitologica Canaria, unpublished data), and blue chaffinches have never been observed far away from their pine forest areas. However, in certain localities of the pine forest of Tenerife, mainly the northeast, blue chaffinches tend to shift their pine seed diet to exploit the seeds of Myrica faya during the winter months when these become abundant (Garcia-del-Rey and Cresswell 2005), a tree belonging to the "monteverde" formation found at lower altitudes and only on north facing slopes of these islands. Seeds of annual plants (Snow and Perrins 1998) are also exploited but only during the spring time when these become available.

\section{Conservation implications}

Spatiotemporal variation of the $P$. canariensis seed crop has not been considered as a relevant factor in the official recuperation plan of the endangered Gran Canaria blue chaffinch (BOC 2005). Until the diet of this finch is rigorously assessed, we recommend trying to improve the seed food supply during the winter season on Gran Canaria, either artificially (i.e., erecting feeders with pine seeds high up in the canopy of younger or fully burned trees to avoid ground-dwelling introduced predators, cats Felis catus) or naturally (i.e., planting $M$. faya in areas suitable for this). These actions will surely minimize adult, but particularly juvenile, over winter mortality of the critically endangered Gran Canaria race. Increasing the pine forest area on this island should be considered as the priority action, particu- 
larly based on the high spatial seed variation observed in this study.

Acknowledgments The first author was supported by the Excmo. Cabildo Insular de Tenerife as a collaboration contract with the Ecology Department of the University of La Laguna and the Forest Anatomy, Physiology and Genetics Unit of the E.T.S. Forestry Engineering (Technical University of Madrid). Earlier version of this manuscript has benefited from the interesting comments of Prof. Christopher M. Perrins, Prof. Ian Newton, and Dr. Will Cresswell (Royal Society University Research Fellow). This manuscript has also benefited from the comments of two anonymous referees.

\section{References}

Baker JR (1938) The evolution of breeding seasons. Evolution: essays presented to E.S. Goodrich (Oxford), pp 161-177

Bannerman DA (1963) Birds of the Atlantic Islands. A history of the birds of the Canary Islands and of the salvages. Oliver \& Boyde, Edinburgh

Bates D (2005) Fitting linear mixed models in R. R News 5:27-30

BirdLife International (2004) Birds in Europe: population estimates, trends and conservation status (BirdLife Conservation Series No. 12). BirdLife International, Cambridge

Boag PT, Grant PR (1984) Darwin's finches (Geospiza) on Isla Daphne Major, Galápagos: breeding and feeding ecology in a climatically variable environment. Ecol Monogr 54:463-489

BOC (2005) 585 DECRETO 57/2005., de 12 de abril, por el que se aprueba definitivamente el Plan de Recuperación del Pinzón Azul de Gran Canaria (Fringilla teydea platzeki)

Bock CE, Lepthien LW (1976) Synchronous eruptions of boreal seedeating birds. Am Nat 110:559-571

Bolker BM, Brooks ME, Clark CJ, Geange SW, Poulsen JR, Stevens MHH, White JSS (2009) Generalized linear mixed models: a practical guide for ecology and evolution. Trends Ecol Evol 24:127-135

Buckingham DL, Peach WJ (2006) Leaving final-cut grass silage in situ over winter as a seed resource for declining farmland. Biodivers Conserv 15:3827-3845

Calama R, Gordo FJ, Mutke S, Montero G (2008) An empirical ecological-type model for predicting stone pine (Pinus pinea $\mathrm{L}$.) cone production in the Northern Plateau (Spain). For Ecol Manage 255:660-673

Chilés JP, Delfiner P (1999) Geostatistics: modeling spatial uncertainty. Wiley, New York, p 695

Clark JS, LaDeau S, Ibanez I (2004) Fecundity of trees and the colonization-competition hypothesis. Ecol Monogr 74:415-442

Clement P, Harris A, Davis J (1993) Finches and sparrows: an identification guide. Princeton University Press, Princeton

Clouet M (2000) The breeding biology of the Common Crossbill Loxia curvirostra in the Central Pyrenees. Bird Study 47:186-194

Critchfield WB, Little EL (1966) Geographic distribution of the pines of the world. USDA Forest Service miscellaneous publication 991. USDA Forest Service, Washington, DC

Garcia-del-Rey E (2003) Comparative ecology of the Canary Island Blue Tit complex (Parus caeruleus teneriffae, P.c. palmensis, P.c. ombriosus, P.c. degener). DPhil thesis, University of Oxford, Oxford

Garcia-del-Rey E (2008) Estudio de la regeneración del pino canario y la influencia del pinzón azul (Fringilla teydea teydea). Island Ecology and biogeography group and Cabildo Insular de Tenerife. Unpublished report

Garcia-del-Rey E, Cresswell W (2005) Density estimates, microhabitat selection and foraging behaviour of the endemic Blue
Chaffinch Fringilla teydea teydea on Tenerife (Canary Islands). Ardeola 52:305-317

Garcia-del-Rey E, Gosler AG (2005) Biometrics, ageing, sexing and moult in the Blue Chaffinch Fringilla teydea teydea on Tenerife (Canary Islands). Ringing Migr 22:177-184

Garcia-del-Rey E, Cresswell W, Perrins CM, Gosler AG (2006) Variable effects of laying date on clutch size in the Canary Island Blue Tits (Cyanistes teneriffae). Ibis 148:564-567

Garcia-del-Rey E, Cresswell W, Perrins CM, Gosler AG (2007a) Evolutionary trends and extreme cases of life history traits in the Canary Island blue tit (Cyanistes teneriffae) on oceanic islands (Canary Islands). Ardeola 54:27-39

Garcia-del-Rey E, Delgado G, Gonzalez J, Wink M (2007b) Canary Island great spotted woodpecker (Dendrocopos major) has distinct mtDNA. J Ornithol 148:531-536

Garcia-del-Rey E, Gil L, Nanos N, Lopez-de-Heredia U, Gil Muñoz P, Fernandez-Palacios JM (2009) Habitat characteristics and seed crops used by Blue Chaffinches Fringilla teydea in winter: implications for conservation management. Bird Study 56:168176

Gibbs HL, Grant PR (1987) Ecological consequences of an exceptionally strong El Niño event on Darwin's finches. Ecology 68:1735-1746

Grant PR (1998) Evolution on islands. Oxford University Press, London

Isatis (2008) Isatis software manual. Geovariances \& Ecole des Mines de Paris, Paris, 579 p

Keeley JE, Zedler PH (2000) Evolution of life histories in Pinus. In: Richardson DM (ed) Ecology and biogeography of Pinus. Cambridge University Press, Cambridge

Krebs JR, Davies NB (1987) An introduction to behavioural ecology. Sinauer Assoc, Sunderland

Lanner RM (1981) The pinion pine. A natural and cultural history. University of Nevada Press, USA

Lanner RM (1996) Made for each other. A symbiosis of birds and pines. Oxford University Press, Oxford

Lanner RM (1998) Seed dispersal in Pinus. In: Richardson DM (ed) Ecology and biogeography of Pinus. Cambridge University Press, Cambridge, pp 285-295

López E, Climent JM, Montero G (2008) Selvicultura de Pinus canariensis Sweet. In: Serrada R, Montero G, Reque JA (eds) Compendio de selvicultura aplicada en España. INIA, Madrid

Marquiss M, Hobson KA, Newton I (2008) Stable isotope evidence for different regional source areas of common crossbill Loxia curvirostra irruptions into Britain. J Avian Biol 39:30-34

Nathan R, Safriel UN, Noy-Meir I, Shiller G (1999) Seed release without fire in Pinus halepensis, a Mediterranean serotinous wind-dispersed tree. J Ecol 87:659-669

Naurois R (1986) Une reproduction de Fringilla t. teydea (Webb Berthelot et Moquin-Tandon) dauns un biotope inattendu (ile de Tenerife, Archipel des Canaries). Cyanopica 3:533-538

Newton I (1972) Finches. Collins, London

Newton I (1998) Population limitation in birds. Academic, San Diego

Newton I (1999) An alternative approach to the measurement of seasonal trends in bird breeding success: a case study of the bullfinch Pyrrhula pyrrhula. J Anim Ecol 68:698-707

Newton I (2006a) Advances in the study of irruptive migration. Ardea 94:433-460

Newton I (2006b) Movement patterns of common crossbills Loxia curvirostra in Europe. Ibis 148:782-788

Perrins CM (1970) The timing of bird's breeding season. Ibis 112:242-255

Perrins CM (1979) British tits. Collins, Glasgow

Pestano J, Brown R, Rodriguez F, Moreno A (2000) Mitochondrial DNA control region diversity in the endangered blue chaffinch, Fringilla teydea. Mol Ecol 9:1421-1425 
Pinheiro J, Bates D (2000) Mixed-effects models in S and S-Plus. Springer, Berlin, $528 \mathrm{p}$

Richardson DM, Rundel PW (2000) Ecology and biogeography of Pinus: an introduction. In: Richardson DM (ed) Ecology and biogeography of Pinus. Cambridge University Press, Cambridge

Schurr FM, Steinitz O, Nathan R (2008) Plant fecundity and seed dispersal in spatially heterogeneous environments: models, mechanisms and estimation. J Ecol 96:628-641

Shaw G (1990) Timing and fidelity of breeding for Siskins Carduelis spinus in Scottish conifer plantations. Bird Study 37:30-35

Siepielski AM, Benkman CW (2007) Convergent patterns in the selection mosaic for two North American bird-dispersed pines. Ecol Monogr 77:203-220

Smith KG, Rotenberry JT (1990) Quantifying food resources in avian studies: present problems and future needs. Studies in Avian Biology No 13:3-5

Snow DW, Perrins CM (1998) The birds of the Western Palearctic. Concise Edition. Volume 2. Oxford University Press, New York
Sutherland WJ, Newton I, Green RE (2004) Bird ecology and conservation: a handbook of techniques. Oxford University Press, New York

Tapias R, Gil L, Fuentes-Utrilla P, Pardos JA (2001) Canopy seed banks in Mediterranean pines of southeastern Spain: a comparison between Pinus halepensis Mill., P. pinaster Ait., P. nigra Arn. and P. pinea L. J Ecol 89(4):629-638

Thibault J-C, Villard P (2005) Reproductive ecology of the Corsican Nuthatch Sitta whiteheadi. Bird Study 52:282-288

Uriarte M, Canham CD, Thompson J, Zimmerman JK, Brokaw N (2005) Seedling recruitment in a hurricane-driven tropical forest: light limitation, density-dependence and the spatial distribution of parent trees. J Ecol 93:291-304

Volsoe H (1955) The breeding birds of the Canary Islands, II: origin and history of the Canarian avifauna. Vidensk Medd Dan Naturhist Foren 113:1-53

Wiens JA (1977) On competition and variable environments. Amer Scient 65:590-597

Wiens JA (1989) The ecology of bird communities: foundations and patterns, vol. 1. Cambridge University Press, Cambridge 